\title{
Teaching in the Time of Covid-19: The Challenges Faced By Teachers in Initiating Online Class Sessions
}

\section{Nurul Ashikin Izhar, Yahya M. Al-dheleai and Kew Si Na}

To Link this Article: http://dx.doi.org/10.6007/IJARBSS/v11-i2/9205

DOI:10.6007/IJARBSS/v11-i2/9205

Received: 13 December 2020, Revised: 17 January 2021, Accepted: 31 January 2021

Published Online: 24 February 2021

In-Text Citation: (Izhar et al., 2021)

To Cite this Article: Izhar, N. A., Na, Y. M. A., \& Na, K. S. (2021). Teaching in the Time of Covid-19: The Challenges Faced By Teachers in Initiating Online Class Sessions. International Journal of Academic Research in Business and Social Sciences, 11(2), 1294-1306.

Copyright: @ 2021 The Author(s)

Published by Human Resource Management Academic Research Society (www.hrmars.com) This article is published under the Creative Commons Attribution (CC BY 4.0) license. Anyone may reproduce, distribute, translate and create derivative works of this article (for both commercial and non-commercial purposes), subject to full attribution to the original publication and authors. The full terms of this license may be seen at: http://creativecommons.org/licences/by/4.0/legalcode

Vol. 11, No. 2, 2021, Pg. 1294 - 1306

Full Terms \& Conditions of access and use can be found at http://hrmars.com/index.php/pages/detail/publication-ethics 


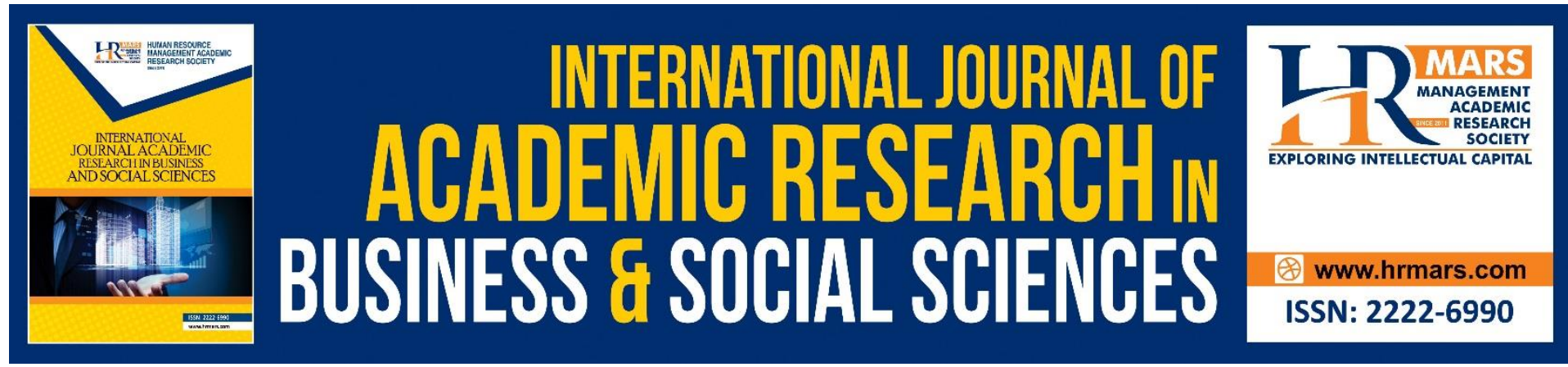

\title{
Teaching in the Time of Covid-19: The Challenges Faced By Teachers in Initiating Online Class Sessions
}

\author{
Nurul Ashikin Izhar ${ }^{1}$, Yahya M. Al-dheleai ${ }^{1}$ and Kew Si Na² \\ School of Educational Studies, Universiti Sains Malaysia, 11800 USM, Pulau Pinang, \\ Malaysia ${ }^{1}$, Language Academy, Faculty of Social Sciences and Humanities, Universiti \\ Teknologi Malaysia, 81310 , Johor Bahru, Johor, Malaysia. ${ }^{2}$
}

\begin{abstract}
The severity of COVID-19 has called the education world to transition into cyberspace education to support the continuity of teaching and learning. The stages of Movement Control Order (MCO), Conditional MCO, and Restricted MCO have resulted in prolonged closure of schools within affected areas. In the Guidelines of Teaching and Learning (T\&L) during MCO,' the Ministry of Education, Malaysia (MoE) has come up with several initiatives for the continuation of education, which include adopting the synchronous and asynchronous modes of online T\&L. Nevertheless, they will not be successful if there are any barriers in the process of implementation. As teachers are the key players in preparing online classes, this research looks into the challenges that arose before they conducted the sessions. One hundred ninetytwo public secondary school teachers responded to this research through open-ended questions. Teachers were asked what the challenges are that they face in preparing, planning, and designing the online lessons. Eight themes emerged in this research; namely, time, environment, technological access, interest, knowledge, technological skills, course design, and communication self-efficacy. This study proposes problems that can be further researched for better online $T \& L$ processes.
\end{abstract}

Keywords: COVID-19 Pandemic, Online Teaching and Learning, Secondary Schools, Sudden School Closure, Emergency Remote Teaching

\section{Introduction}

The COVID-19 pandemic has affected education drastically as the worldwide closure of learning institutions has caused 1.5 billion students to lose their chance of undergoing normal education (World Health Organization [WHO], 2020; United Nations, 2020). In Malaysia, the enforcement of Movement Control Order (MCO) on March 18, 2020 has transitioned $1,805,706$ public secondary school students and 149,707 teachers from face-to-face physical interaction in the classroom into cyberspace education (Ministry of Education, 2020a). Nevertheless, the implementation of online T\&L was rather sudden that it was only a matter of days. Thus, it remains ambiguous how teachers shifted their gear. Online T\&L took place in a few stages in Malaysia; MCO, Restricted MCO, and Conditional MCO. In this article, the term 
MCO is referred to as the three stages where online education happened during school closure (Ministry of Education, 2020b).

\section{Literature Review}

Teachers constitute one of the most important pillars in an education system Teachers' knowledge and experience will influence the delivery of their lessons and the use of pedagogies in their instructional T\&L (Mishra \& Mehta, 2017). Integrating technology as part of the instructional tools possesses the potential to enhance T\&L (Doolittle \& Hicks, 2003). In order to use ICT successfully in T \& L, teachers need to master the knowledge and skills in terms of technology integration (Garba, Byabazaire, \& Busthami, 2015). To put it succinctly, for the best student learning outcome, it is necessary to incorporate suitable technology in T\&L (Mynbayeva, Sadvakossova, \& Akshalova, 2017).

Looking into the need of having online lessons during the pandemic as a mechanism to control the outbreak of the virus and continue education from home, teachers are urged to recognize the undeniable benefits of using technology for education continuation (United Nations, 2020; UNESCO, 2020). This is because teachers play a crucial role in ensuring the success of education continuation and the use of technology is stated in the 'Guidelines of Teaching and Learning (T\&L) during MCO' (Ministry of Education, 2020b; 2020c).

In the current situation, not only do teachers need to apply suitable teaching strategies to achieve their lesson objectives, but they also need to consider other external factors that are able to contribute to the success of online teaching (Zhang, Wang, Yang, \& Wang, 2020). According to Abdous(2011), different phases of online T\&L demand different competencies, reason being that, online T\&L involves preparing, planning and designing the lesson in the first phase (Before phase); then, it is followed by During the lesson phase and the third phase, which is After phase. Even though the framework proposed by Abdous (2011) in Figure 1 was developed to elicit the competencies a teacher needs to possess for online $T \& L$, in this research, the framework was adapted to find out the challenges faced by teachers when conducting online classes.

\section{Figure 1. A process-oriented framework adapted from Abdous (2011) to derive online teaching challenges during school closure.}

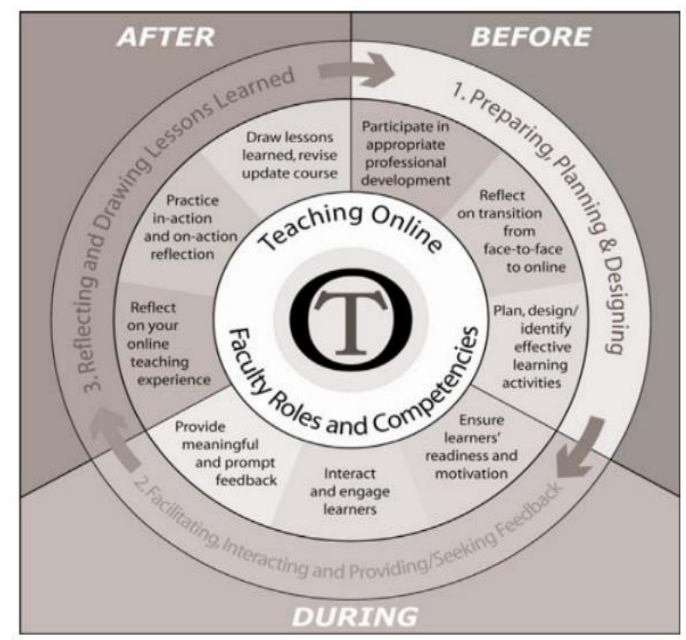

In this framework, process and preparation is taken into consideration in all the three phases. In other words, it takes place in Before the T\&L, During T\&L, and After T\&L. However, 
this research focuses on the Before phase to investigate challenges faced by teachers in the process of preparing, planning, and designing which take place prior to online T\&L activities. The online teaching framework by Abdous (2011) was tested in a higher education setting. This study, on the other hand, attempts to extend the framework into secondary school settings. Moreover, it is worth noting that the scenario of substituting face-to-face education entirely with online education as a pedagogical strategy to ensure education continuation has never happened in Malaysia before. Therefore, the previous researches in online learning mostly focused on blended learning (Ramli \& Saleh, 2019; Awang et al., 2018; Cheok, Wong, Ayub, \& Mahmud, 2017; Hashim, Nasri, \& Mustafa, 2016). Thus, this paper represents a novel research that focuses on challenges faced by teachers in preparing for full time online T\&L during the school closure in conjunction with MCO. It is important to study the challenges that hinder the success of online T\&L (González-Sanmamed, Sangrà, \& Muñoz-Carril, 2017) so they can be taken into consideration and dealt with in the future planning of online learning.

\section{Methodology}

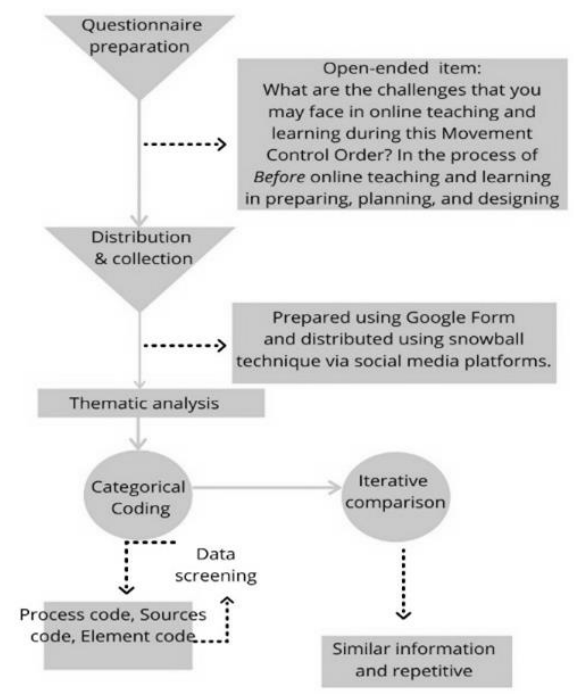

Figure 2. The procedure employed in this research

In this study, four major processes as shown in Figure 2 were carried out; (1) preparing questionnaire, (2) distributing the questionnaire and collecting data, (3) categorical coding, and (4) thematic analysis of the responses to open-ended questions. The respondents were asked to recall the challenges that they have faced while preparing, planning and designing their online class sessions. The open-ended questions allowed the respondents to write down whatever challenges that they perceived as hurdles in accomplishing the task of preparing, planning and designing the online lessons (Fletcher, Everatt, Mackey, \& Fickel, 2020). The open-ended questions underwent back-to-back translation from English to Bahasa Melayu (the national language in Malaysia) and vice versa by two experts in both languages. Furthermore, the content validity was checked by two experts in the field of educational technology.

The questionnaire was then prepared virtually using Google Form applications and distributed via social media groups that consist of professional Malaysian teachers, which include Facebook, Telegram, and Whatsapp. The respondents of this study are secondary public school teachers around Malaysia. When distributing the questionnaire, the snowball 
technique was employed whereby every respondent is encouraged to share the link with their colleagues who share the same criteria (secondary public school teacher). In short, online survey was chosen as the mode of questionnaire distribution and data collection in this study.

The researchers received 192 responses. Through data screening, it was found that among the 192 responses, 182 were answered by secondary school teachers and the remaining were responses made by primary school teachers. As this research focuses on secondary school teachers, only 182 responses were used for iterative comparison to elicit the themes that arose in this study by looking into data that shared similar information and data that were repetitive.

Table 1: Sample Scheme to code and organise data according to the themes Examples excerpts Element codes (145) Some of the materials are in hardcopy. And I could not reach Resources them since they were in my school place while I'm at home. (54) Not confident as I am from the older generation.

Confident

\section{Results and Discussion}

Emergent themes and their descriptive analysis in the collected data, 182 respondents reflected their challenges in Before phase where a teacher prepares, plans and designs a lesson before conducting online T\&L. The data were analysed, processed with iterative comparison and summarised in Table 2.

Table 2: Challenges and themes that emerged in the study.

\begin{tabular}{|c|c|c|c|}
\hline Themes & Example of excerpts & $\begin{array}{l}\text { Number of } \\
\text { occurrences }\end{array}$ & $\begin{array}{c}\text { Percentage } \\
\text { (\%) }\end{array}$ \\
\hline $\begin{array}{l}\text { Communication } \\
\text { self-efficacy }\end{array}$ & $\begin{array}{l}\text { [123] "Hard to expressing my thoughts in writing } \\
\text { and sometimes I'm used voice note to deliver my } \\
\text { voice tone to students". }\end{array}$ & 10 & 5.0 \\
\hline Course design & $\begin{array}{l}\text { [35] "Looking for suitable learning materials for } \\
\text { every levels of student" }\end{array}$ & 35 & 17.6 \\
\hline Knowledge & $\begin{array}{l}\text { [146] "Delivering content knowledge is the } \\
\text { hardest part. Students tend to not read before } \\
\text { class. Even when I've told them to read. Lecture on } \\
\text { teams meeting not a good way. Basically, I don't } \\
\text { think I know how to prepare a good lesson for } \\
\text { synchronise lesson" }\end{array}$ & 38 & 19.1 \\
\hline $\begin{array}{l}\text { Technological } \\
\text { skills }\end{array}$ & $\begin{array}{l}\text { [126] "Tak mahir menggunakan Google } \\
\text { classroom" } \\
\text { Translation: "Not proficient in using Google } \\
\text { Classroom" }\end{array}$ & 60 & 30.2 \\
\hline $\begin{array}{l}\text { Technological } \\
\text { access }\end{array}$ & $\begin{array}{l}\text { [166] “Internet tidak stabil (lemah)" } \\
\text { Translation: “Unstable internet connection (poor } \\
\text { internet)" }\end{array}$ & 36 & 18.1 \\
\hline Environment & [58] "Household chores" & 7 & 3.5 \\
\hline Interest & $\begin{array}{l}\text { [55] "not interested in using online teaching and } \\
\text { learning applications" }\end{array}$ & 1 & 0.5 \\
\hline Time & $\begin{array}{l}\text { [4] "Time constraint to spend on online teaching } \\
\text { and learning." }\end{array}$ & 12 & 6.0 \\
\hline & Total & 199 & 100.0 \\
\hline
\end{tabular}




\section{Knowledge and Technological skills}

During the sudden transition into online education, teachers were expected to be able to use the online learning platforms immediately (Zhang et al., 2020). However, teachers reported that they lacked knowledge and skills to convert offline (hardocpy) materials into online (softcopy) materials and share them on online platforms. Having limited experience in online teaching caused a lack of online teaching skills among teachers. Thus, they faced challenges in preparing teaching materials that can cater to students of different levels, creating suitable methods for all students, and preparing synchronous lessons. Teacher 101 highlighted that online teaching requires thorough preparation, "teacher knowledge in using online resources are not enough," she also mentioned that she spent a tremendous amount of time to prepare for herlessons, "need to take a long time in preparing the materials". Her encounter was similar to Teacher 97, who pointed out that online teaching was challenging because teachers had very limited practical experience in using online platforms to teach before the school closure.

The ability to integrate technology, content, and pedagogy based on knowledge and skills contributes to an effective lesson delivery. Therefore, these knowledge and skills are crucial for teachers in this era. According to Koehler, Mishra and Cain (2013), Technology Pedagogy Knowledge (TPK) refers to a teacher's expertise in altering the T\&L process in correspondence with a particular technology that is newly introduced, whereas Technology Content Knowledge (TCK) is the understanding of specific techniques that complement the teaching of the subject matter. In this regard, Teacher 50 stated that, "I need to plan my teaching and learning with simplified and easy to follow,". However, challenges arose when teachers were unable to provide learning platforms with appropriate lesson designs and plans, "I am lacking in skills to provide learning resouurces such as using video with the lesson plan for the teaching and learning process on the online platforms" (Teacher 181). It was a struggle, especially for novice teachers, to switch from T\&L sessions in physical classrooms to online T\&L. Even though most people own internet-connected devices such as smartphones, it cannot be assumed that they are technology-literate, let alone being able to teach using technology. The data released by Department of Statistics Malaysia (2020) shows that $97.1 \%$ of internet users in Malaysia acknowledge social interactions as their main internet activity, $84.7 \%$ ddownload images, videos, musics and games online and $83.5 \%$ use the internet to find information related to goods and services (Department of Statistics Malaysia, 2020). In summary, this report reveals that the internet is seldom used for academic purposes.

\section{Technological access}

The access to technology appears to be the most reported challenge that hinders the smooth flow of online T\&L sessions. Limited internet access due to unstable internet connection, unstable internet speed, and insufficient data for those who are using mobile data are among the challenges that arose under this theme. It is of utmost importance to look into this particular issue as online teaching and learning requires frequent synchronised and asynchronised communication (Akbulut, Şahin, \& Esen, 2020; Awang et al., 2018). An unstable internet connection will result in a less effective lesson delivery. In the other hand, unreliable devices or gadgets is another obstacle in online T\&L even if the internet connection is stable (Sadeghi, 2019). Quality technology infrastructure should be prioritized as recommended by UNESCO and OECD to ensure education continuation using the online learning platforms (UNESCO, 2020; Reimers \& Schleicher, 2020). However, this issue has not been resolved 
satisfactorily since the utilisation of VLE-Frog for learning management system (Ramli \& Saleh, 2019; Awang et al., 2018).

Zhang et al., (2020); and Akbulut et al. (2020) reported the access to technology as the most prevalent challenge that arose in their respective study. Zhang et al. (2020) highlighted that online learning systems often become overwhelmed and crash due to large volumes of users. Besides, places with challenging geographical structures, such as mountainous and rural localities, usually have little to no access to technology. In this study, Teacher 34 voiced out that, "....slow or sometimes no internet access," was what she faced while preparing for online classes. As asserted by Akbulut et al. (2020) the fact that not everyone is privileged to have access to either internet or computers makes online education unfair. For instance, Teacher 37 discussed the suitability to use asynchronous mode of teaching; "I need to think of the correct method and platform to use so that it won't burden my students and it is easy for them to access the materials. For example, I don't think video conferencing is suitable for Malaysian school students as not all families afford to provide a mobile phone for their kids. Hence, some need to lend their phones to their kids. So I need to spend some time to do a brief research on which platform is suitable to be used for that particular lesson'.

Zhang et al. (2020) discovered that technology infrastructure was the main challenge in the implementation of 'Suspending Class without Stopping Learning'. Internet availability and stability, as well as internet-connected devices such as laptops and smartphones are the two most crucial elements in online T\&L. Thus, without proper internet and devices, the lesson cannot take place. However, it is no surprise that the best technology infrastructure is unaffordable in a time where people are financially challenged due to restriction of movement to contain COVID-19 outbreak (Dhawan, 2020). Many are influenced by salary reduction, and some even lost their jobs (United Nations, 2020). During the crisis, people prioritize spending on the essentials for survival over the other needs (Reimers \& Schleicher, 2020). Therefore, in such circumstances, the government and private sectors need to sponsor the access to technology for suburban teachers and students and the under privileged.

\section{Course Design}

Teacher 146 mentioned that "Delivering content knowledge is the hardest part. Students tend to not read before class. Even when I've told them to read. Lecture on teams meeting not a good way. Basically, I don't think I know how to prepare a good lesson for synchronise lesson". Apart from that, the school's management have shown support by simplifying the lesson plan for teachers. Teacher 173 reported that 'management request us doing daily lesson plan based on school timetable where only notes needed and flexible time'. Difficulties in designing online $T \& L$ was expressed by Teacher 188, "difficulties in planning and designing interesting activities that attract students interest," ; ergo, it is clear that online teaching requires a specialised skill set in terms of how to teach, how and when to use either synchronous, asynchronous or both teaching strategies, preparing and designing a lesson, gathering feedback, and reflecting lessons taught (Martin, Budhrani, Kumar, \& Ritzhaupt, 2019a; Abdous, 2011).

Although the MoE has provided plenty of online learning platforms such as Digital Textbook, EduwebTv, and CikgooTube, insufficiency of adequate materials was still reported as one of the challenges as the most of the materials are in hardcopy and placed in schools. Teacher 145 complained that "Some of materials are in hardcopy. And I could not reach them since they were in my school place while I'm at home,". Moreover, finding materials that are 
compliant with school syllabus and appropriate for students' comprehension level is another challenge faced by the teachers. For examples, 'looking for suitable learning materials for every level of students is quite challenge as most are at school,' (Teacher 35), and 'limited teaching resources because most of it are international syllabus', (Teacher 47).

Course design involves lesson planning with appropriate objectives, instructional strategies, activities and assessments (Martin, Budhrani, \& Wang, 2019b). In general, a complete online class requires a thorough lesson plan design, teaching materials and a technology support team (Bao, 2020). To assist teachers in shifting from traditional face-to-face teaching to online teaching, the MoE has collaborated with UNICEF Malaysia to create Digital Learning Teachers Community (Komuniti Guru Digital Learning - Modul 1 - 5) that consists of five training modules to guide teachers from the basic level of how to start an online teaching plaform to the more advanced level of how to establish a positive digital platform (Ministry of Education, 2020d). The effort made to provide teaching support during the crisis is in accordance with what has been suggested by the United Nation, UNESCO, and OECD (United Nations, 2020; UNESCO, 2020; Reimers \& Schleicher, 2020).

As reviewed by Zhang et al. (2020), knowledge and technological skills supplement the competencies needed in online teaching; nonetheless, many teachers find it challenging to integrate suitable pedagogies in their online clases.Teaching in a virtual environment is not as easy as it seems as it involves a great deal of preparation such as developing and delivering the content, executing the lesson, tracking and reporting students' progress, and integrating other softwares into one learning platform (Ramli \& Saleh, 2019; Watson \& Watson, 2007; Alias \& Zainuddin, 2005). The pedagogical practices of teachers, as in how they incorporate technology in their teaching, vary depending on individual preferences, different natures of subjects, as well as unique school settings (Szeto \& Cheng, 2017).

Time

As teachers who never attempted to use online platforms in their T\&L were required to pick up news skills out of a sudden, many of them spent a lot of time groping in the dark. In fact, even teachers with prior experience in using online learning tools for blended learning opined that the preparation of online lessons was time consuming (Akbulut et al., 2020). For instance, Teacher 4 and Teacher 162 mentioned that they faced time constraints in online T\&L. Teacher 44 admitted that she always took 2 to 3 hours' worth of extra time preparing the materials. This issue arose because teachers were not familiar with the chosen online teaching platforms (Zhang et al., 2020; Zhou, Wu, Zhou, \& Li, 2020) and the ways to look up materials that suit the national syllabus. Besides, teaching from home during school and nursery closure added parental burden on some teachers as time management was a big challenge for them.

Communication self-efficacy

According to Martin et al. (2019a), an ideal online T\&L session occurs when the teacher has the ability in communicating and completing the online task. In this research, communication self-efficacy involves a teacher's ability in expressing himself or herself through writing, video/audio, conducting either synchronous or asynchronous lesson, and how a teacher uses the available online applications such as Google Classroom for LMS or social media platforms such as Whatsapp and Telegram for effective communication in online T\&L. In this study, Teacher 2 highlighted that she encountered challenges in asking students to do their task, whereas for Teacher 10, she had issues in, 'gathering all students in one Whatsapp group as a class'. 
Before the school closure, teachers and students were able to interact physically and use face expressions to communicate their emotions. In line with this, Teacher 22 , highlighted that ' can't face-to-face with students and look out their facial expression and behaviour, and body movement'. According to Teacher 107 and 103, the online T\&L situation rendered it difficult for teachers to know whether or not students understood the content matter or enjoyed the class, as traditionally, observation is one of the most common methods used by teachers in doing reflections (Tseng \& Yeh, 2019).

Besides, teachers had less confidence communicating in the online T\&L environment as most of the time, they use online platforms only for social interaction. Teacher 54 attributed her lack of confidence to age, "not confident as I am from the older generation".

\section{Environment}

During the movement control, teaching was conducted at teachers' respective houses. In relation with that, a teacher's home environment plays a role in determining the success of an online class (Zhang et al., 2020; Zhou et al., 2020). As the first country in the world that implemented education continuation via online platforms, China discovered that environmental distractions such as house chores and kids were significant challenges faced by teachers when conducting online classes (Zhang et al., 2020). Teachers who are also parents are more susceptible to their home environment which may influence their focus on online classes (Zhang et al., 2020). As their kids were also at home due to school closure, they had to do juggle between house chores such as preparing meals, monitoring their kids' online classes, and cleaning and the preparation of their online classes (Reimers \& Schleicher, 2020; Zhang et al., 2020). The similar was reported by Teacher 68 , 'my kids still in primary school. They also need to use the internet and be monitored,' while Teacher 179 confessed that, 'my home environment is not conducive,' and Teacher 183 talked about, '.....the needs of kids at home'. In general, the double demands of house chores and online teaching at home posed an influential challenge to online teaching (Kumar \& Bervell, 2019; Awang et al., 2018). Interest

A teacher will not be able to fully utilize online classes to ensure education continuation if he does not experience the benefits of online classes (Akbulut et al., 2020). Not only that, a teacher will even be highly reluctant to conduct online classes if he finds it complicated and not useful (Moses, Wong, Bakar, \& Mahmud, 2013). For example, Teacher 51 expressed that he or she is 'not interested in using online teaching and learning applications', thus, this teacher did not conduct any online lessons during the school closure. This issue should be addressed as it will deprive students of their right to receive education and they will be left behind. United Nation (2020) is concerned that sudden school closures might pose a threat on students' learning opportunities. Teachers' lack of interest in conducting online classes will worsen the situation.

\section{Conclusion}

This research offers several implications towards the online learning environment in Malaysia, particularly during the sudden school closure due to COVID-19 pandemic. Firstly, this research explores the challenges faced by teachers in initiating smooth and successful online classes. According to Upadhyaya \& Mallik (2013), online T\&L is a form of education that intertwines social interaction (e.g. teacher, student, parent) and technical system (e.g. platform, facilities, system, program). The results of this study are conceptualized in Figure 3 where there are intervening challenges between social aspects and technical aspects that are derived from 
teachers. Meanwhile, according to UNESCO (2020), Reimers \& Schleicher (2020), and United Nations (2020), access to technology, environment, and health are critical criteria that contribute to the success of an online class session.

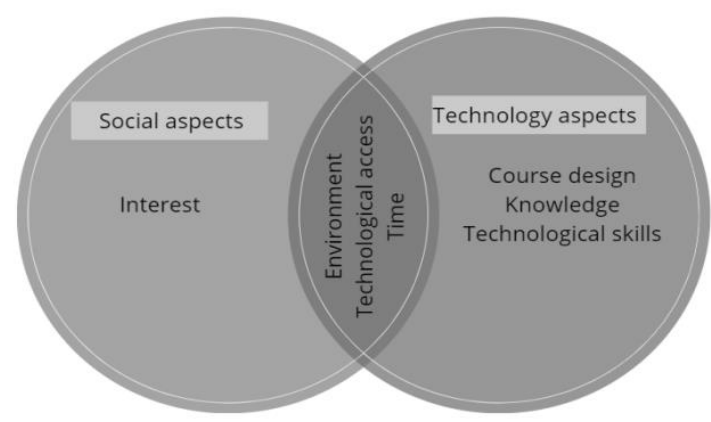

Figure 3. Challenges faced by the teacher in online T\&L during sudden school closure due to COVID-19 pandemic.

It is suggested that future researchers explore the challenges with respect to social structure (teachers, students, parents) in depth that hinder them from conducting a successful online T\&L session. In addition, as this study only adopted an open-ended questionnaire, it is recommended that future research employ quantitative methodologies such as in-depth interviews to refine the results derived from this study.

Since not all online classes are created the same way, to understand how different modes of T\&L are related to students' experiences and learning in online classes, teachers are encouraged to study what constitutes effective instructional design in online contexts (Chyr, Shen, Chiang, Lin, \& Tsai, 2017). Improving the challenges that emerged during the crisis is an essential step to build desirable, compelling and successful online education (Mastel-Smith, Post, \& Lake, 2015). It can also enhance the planning of stakeholders in terms of leveraging technology to enhance teaching quality.

\section{Acknowledgement}

We would like to thank all the respondents that have helped in conducting this study.

\section{Corresponding Author}

Yahya M. al-dheleai, School of Educational Studies, Universiti Sains Malaysia, 11800 USM, Pulau Pinang, Malaysia.

Email: yamohd3@gmail.com

\section{References}

Abdous, M. (2011). A process-oriented framework for acquiring online teaching competencies. Journal of Computing in Higher Education, 23(1), 60-77. https://doi.org/10.1007/s12528-010-9040-5

Akbulut, M., Şahin, U., \& Esen, A. C. (2020). More than a virus: How COVID 19 infected education in Turkey? Journal of Social Science Education, 19(1), 30-42. https://doi.org/10.4119/jsse-3490

Alias, N., \& Zainuddin, A. (2005). Innovation for better teaching and learning: Adopting the learning management system. Malaysian Online Journal of Instructional Technology, 2(2), 27-40. 
Awang, H., Aji, Z. M., Yaakob, M. F. M., Osman, W. R. S., Mukminin, A., \& Habibi, A. (2018). Teachers' intention to continue using Virtual Learning Environment (VLE): Malaysian context. Journal of Technology and Science Education, 8(4), 439-452. https://doi.org/10.3926/jotse.463

Bao, W. (2020). COVID-19 and online teaching in higher education: A case study of Peking University. Human Behavior and Emerging Technologies, 1-3. https://doi.org/10.1002/hbe2.191

Cheok, M. L., Wong, S. L., Ayub, A. F., \& Mahmud, R. (2017). Teachers' perceptions of elearning in Malaysian secondary schools. Malaysian Online Journal of Educational Technology, 5(2), 20-33.

Chyr, W. L., Shen, P. D., Chiang, Y. C., Lin, J. B., \& Tsai, C. W. (2017). Exploring the effects of online academic help-seeking and flipped learning on improving students' learning. Educational Technology \& Society, 20(3), 11-23. https://doi.org/10.2307/26196116

Department of Statistics Malaysia. (2020). ICT use and access by individuals and households survey report 2019, Malaysia. In 10th April 2020. Putrajaya. Retrieved from https://www.dosm.gov.my/v1/index.php?r=column/pdfPrev\&id=SFRacTRUMEVRUFo1 Ulc4Y1JILzBqUT09

Dhawan, S. (2020). Online learning: A panacea in the time of COVID-19 crisis. Journal of Educational Technology Systems, 49(1), 5-22. https://doi.org/10.1177/0047239520934018

Doolittle, P. E., \& Hicks, D. (2003). Constructivism as a theoretical foundation for the use of technology in social studies. Theory and Research in Social Education, 31(1), 72-104. https://doi.org/10.1080/00933104.2003.10473216

Fletcher, J., Everatt, J., Mackey, J., \& Fickel, L. H. (2020). Digital technologies and innovative learning environments in schooling: A New Zealand experience. New Zealand Journal of Educational Studies, 55(1), 91-112. https://doi.org/10.1007/s40841-020-00156-2

Garba, S. A., Byabazaire, Y., \& Busthami, A. H. (2015). Toward the use of 21 st century teaching- learning approaches: The trend of development in Malaysian schools within the context of Asia Pacific. International Journal of Emerging Technologies in Learning, 10(4), 72-79. Retrieved from http://dx.doi.org/10.3991/ijet.v10i4.4717\%0A

González-Sanmamed, M., Sangrà, A., \& Muñoz-Carril, P. (2017). We can, we know how. But do we want to? Teaching attitudes towards ICT based on the level of technology integration in schools. Technology, Pedagogy and Education. http://dx.doi.org/10.1080/1475939X.2017.1313775

Hashim, H., Nasri, S. M. M., \& Mustafa, Z. (2016). Teachers' challenges in the implementation of frog virtual learning environment in the classrooms. Asia Pacific Journal of Educators and Education, 31, 115-129.

Koehler, M. J., Mishra, P., \& Cain, W. (2013). What is Technological Pedagogical Content Knowledge (TPACK)? Journal of Education, 193(3), 13-19. https://doi.org/10.1177/002205741319300303

Kumar, J. A., \& Bervell, B. (2019). Google classroom for mobile learning in higher education: Modelling the initial perceptions of students. Education and Information Technologies, 24(2), 1793-1817. https://doi.org/10.1007/s10639-018-09858-z

Martin, F., Budhrani, K., Kumar, S., \& Ritzhaupt, A. (2019a). Award-winning faculty online teaching practices: Roles and competencies. Online Learning Journal, 23(1), 184-205. https://doi.org/10.24059/olj.v23i1.1329

Martin, F., Budhrani, K., \& Wang, C. (2019b). Examining faculty perception of their readiness 
to teach online. Online Learning Journal, 23(3), 97-119. https://doi.org/10.24059/olj.v23i3.1555

Mastel-Smith, B., Post, J., \& Lake, P. (2015). Online teaching: Are you there, and do you care? Journal of Nursing Education, 54(3), 145-151. https://doi.org/10.3928/0148483420150218-18

Ministry of Education. (2020a). Statictic number of schools, students, and teachers (Statistik Bilangan Sekolah, Murid dan Guru). Retrieved April 10, 2020, from https://www.moe.gov.my/statistik-menu/statistik-bilangan-sekolah-murid-guru

Ministry of Education. (2020b). Media statement: Implementation of teaching \& learning during movement control order (Kenyataan Media: Pelaksanaan Pengajaran dan Pembelajaran berikutan Perlanjutan Tempoh Perintah Kawalan Pergerakan). Putrajaya. Retrieved from https://www.moe.gov.my/pemberitahuan/kenyataanmedia/kenyataan-media-pelaksanaan-pengajaran-dan-pembelajaran-berikutanperlanjutan-tempoh-perintah-kawalan-pergerakan

Ministry of Education. (2020c). Media statement: FAQ's regarding school/instituitions closure under the Ministry of Education Malaysia [Soalan Lazim berkaitan Penutupan Sekolah/Instituisi Pendidikan di bawah Kementerian Pendidikan Malaysia]. Retrieved November 10, 2020, from Ministry of Education website: https://www.moe.gov.my/en/pemberitahuan/media-statement/km-faq-berkaitanpenutupan-sekolah-institusi-pendidikan-kpm

Ministry of Education. (2020d). Digital learning teachers community with MOE (Komuniti Guru Digitial Learning bersama KPM). Retrieved May 4, 2020, from https://sites.google.com/moe-dl.edu.my/ldp-digital-learning/home?authuser=1

Mishra, P., \& Mehta, R. (2017). What we educators get wrong about 21st-century learning: Results of a survey. Journal of Digital Learning in Teacher Education, 33(1), 6-19. https://doi.org/10.1080/21532974.2016.1242392

Moses, P., Wong, S. L., Bakar, K. A., \& Mahmud, R. (2013). Perceived usefulness and perceived ease of use: Antecedents of attitude towards laptop use among science and mathematics teachers in Malaysia. Asia-Pacific Education Researcher, 22(3), 293-299. https://doi.org/10.1007/s40299-012-0054-9

Mynbayeva, A., Sadvakossova, Z., \& Akshalova, B. (2017). Pedagogy of the twenty-first century: Innovative teaching methods. In O. B. Cavero \& N. Llevot-Calvet (Eds.), New Pedagogical Challenges in the 21st Century - Contributions of Research in Education. IntechOpen. https://doi.org/http://dx.doi.org/10.5772/57353

Ramli, N., \& Saleh, S. (2019). FrogVLE application in science teaching in secondary schools in North Malaysia: Teachers' perspective. Education Sciences, 9(4), 1-11. https://doi.org/10.3390/educsci9040262

Reimers, F., \& Schleicher, A. (2020). A framework to guide an education response to the COVID-19 pandemic of 2020. Organisation for Econmoic Co-Operation and Development (OECD), 227-2268. https://doi.org/10.3102/00346543066003227

Sadeghi, M. (2019). A shift from classroom to distance learning: Advantages and limitations. International Journal of Research in English (IJREE), 4(1), 80-88.

Szeto, E., \& Cheng, A. Y. N. (2017). Pedagogies across subjects: What are preservice teachers' TPACK patterns of integrating technology in practice? Journal of Educational Computing Research, 55(3), 346-373. https://doi.org/10.1177/0735633116667370

Tseng, S. S., \& Yeh, H. C. (2019). Fostering EFL teachers' CALL competencies through projectbased learning. Educational Technology and Society, 22(1), 94-105. 
United Nations Educational Scientific and Cultural Organization (UNESCO). (2020). UNESCO COVID-19 education response education sector issue notes: Distance learning strategies in response to COVID-19 school closures.

United Nations. (2020). Policy brief: Education during COVID-19 and beyond (August 2020) World I ReliefWeb. (August), 26. Retrieved from https://reliefweb.int/report/world/policy-brief-education-during-covid-19-andbeyond-august-2020

Upadhyaya, K. T., \& Mallik, D. (2013). E-Learning as a socio-technical system: An insight into factors influencing its effectiveness. Business Perspectives and Research, 2(1), 1-12. https://doi.org/10.1177/2278533720130101

Watson, W. R., \& Watson, S. L. (2007). An argument for clarity: What are learning management systems, what are they not, and what should they become? TechTrends, 51(2), 28-34. https://doi.org/10.1007/s11528-007-0023-y

World Health Organization (WHO). (2020). WHO Director-General's opening remarks at the media briefing on COVID-19. Retrieved May 14, 2020, from WHO website: https://www.who.int/dg/speeches/detail/who-director-general-s-opening-remarks-atthe-media-briefing-on-covid-19---11-march-2020

Zhang, W., Wang, Y., Yang, L., \& Wang, C. (2020). Suspending classes without stopping learning: China's education emergency management policy in the COVID-19 outbreak. Journal of Risk and Financial Management, 13(3), 1-6. https://doi.org/10.3390/jrfm13030055

Zhou, L., Wu, S., Zhou, M., \& Li, F. (2020). 'School's out, but class' on', the largest online education in the world today: Taking China's practical exploration during the COVID-19 epidemic prevention and control as an example. Best Evidence Chinese Education, 4(2), 501-519. https://doi.org/10.2139/ssrn.3555520 